\title{
La revue Radioprotection acquiert un nouveau sous-titre : The International Journal of the French Society for Radiation Protection
}

\section{Un changement de nom pour un nouvel horizon!!}

Après quelques années d'évolution, la revue Radioprotection accède à la pleine maturité et compte désormais dans le paysage de l'édition scientifique. L'année 2015 est marquée par un nouveau record en termes d'articles soumis ; leur nombre a augmenté de $30 \%$, alors même que de nouveaux supports moins contraignants venaient concurrencer sérieusement les revues classiques, à comité de lecture. Notre lectorat s'accroit sans cesse et les auteurs viennent maintenant du monde entier pour proposer des articles scientifiques et techniques émanant de tous les domaines de la radioprotection. Cette évolution doit évidemment être prise en compte et il nous parait juste de leur rendre hommage et de publier la plupart de nos colonnes en anglais, qui est et reste la langue de référence pour toutes les disciplines scientifiques. Ce changement de portage ne pouvait s'accomplir sans une adaptation du sous-titre de notre revue, afin de mettre plus clairement en exergue le rôle et le soutien indéfectible de la Société Française de Radioprotection dans l'édition de notre journal, mais également la portée internationale de nos débats et des travaux qui y sont décrits.

Le comité éditorial s'est à son tour adapté aux pratiques internationales et repose à présent sur une équipe composée d'un rédacteur en chef et de rédacteurs associés, dont les expériences professionnelles variées assurent un très large spectre de compétences complémentaires pour une sélection toujours plus rigoureuse et pertinente des articles soumis à publication.

Je souhaite une très longue vie à The International Journal of the French Society for Radiation Protection et espère vous rassembler toutes et tous autour de ce journal dont l'ambition est d'avancer dans un esprit d'ouverture, dans tous les domaines de la radioprotection et avec une rigueur et une exigence éditoriale qui contribueront à faire avancer savoirs et pratiques par vos écrits et vos analyses.

\section{The journal Radioprotection has got a new subtitle: The International Journal of the French Society for Radiation Protection}

\section{A new name for a new horizon!!}

After several years of evolution, the journal Radioprotection reaches now full maturity and become significant in the landscape of scientific publishing. The year 2015 was marked by a new record in terms of papers submitted; their number increased by $30 \%$, despite the development of new less restrictive journals, competing seriously with conventional journals with referees. Our readership is growing constantly and now authors from all around the world submit to our journal scientific and technical papers from every fields of radiological protection. This development must be taken into account and it seems just to honor them and to publish most of our papers in English, which is and remains the language of reference for all scientific disciplines. This change could not be accomplished without any change of the subtitle of our journal, in order to more clearly highlight the unwavering support of the French Society for Radiological Protection for its publication, but also the international scope of the work described and published in its pages. 
The editorial committee is in turn adapted to international practice and is now based on a team consisting of an editor and associate editors, whose varied professional experiences provide a very wide range of complementary skills for a rigorous and relevant evaluation of the papers submitted for publication.

I wish a very long life to The International Journal of the French Society for Radiation Protection and hope to gather you all around this journal, which aim is to move forward in a spirit of openness in all areas of radiological protection, and to advance on knowledge and practices with your writing and your analyzes.

François Paquet Editor in Chief 